\title{
Carbon isotope variations in the Upper Carboniferous - Permian Mallemuk Mountain Group, eastern North Greenland
}

\author{
LARS STEMMERIK and MORDECKAI MAGARITZ
}

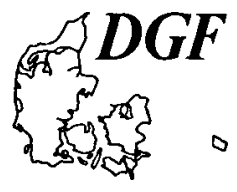

\begin{abstract}
Stemmerik, L. and Magaritz, M.: Carbon isotope variations in the Upper Carboniferous - Permian Mallemuk Mountain Group, eastern North Greenland. Bull. Geol. Soc. Denmark, Vol. 37, pp. 205-211, Copenhagen, April 10th, 1989. https://doi.org/10.37570/bgsd-1988-37-16

Isotope data from Late Palaeozoic limestones of the Wandel Sea Basin in eastem North Greenland show a variation of $\delta^{13} \mathrm{C}$ from $0.0 \%$ to $5.7 \%$ vs PDB. Carbonates depleted in ${ }^{13} \mathrm{C}$ occur in the basal part of lower Moscovian, upper Moscovian and middle Gzhelian transgressive sequences. ${ }^{13} \mathrm{C}$ enriched limestones occur later in the cycles. The most ${ }^{13} \mathrm{C}$ enriched limestones occur in the youngest (late Early Permian-early Late Permian) part of the sequence in Amdrup Land. The isotopic data is believed to represent changes in the global carbon cycle. Thus ${ }^{13} \mathrm{C}$ enriched carbonates correlate to periods of burial of organic carbon mostly as coal, while ${ }^{13} \mathrm{C}$ depleted carbonates formed as the result of erosion and oxidation of organic carbon during sea-level low stands.
\end{abstract}

Lars Stemmerik, Geological Survey of Greenland, Øster Voldgade 10, DK-1350 Copenhagen K, Denmark. Mordeckai Magaritz, Isotope Research Department, Weizmann Institute of Science, Rehovot 76100, Israel. October 13th, 1988.

\section{Introduction}

Chemical events, especially those with isotopic signatures, are being increasingly recognized in the marine record (Holser 1984). Carbon isotope ratios in marine rocks have been shown to vary in response to geological events on several time scales. In the Pleistocene from glacial to interglacial time $\delta^{13} \mathrm{C}$ increased sharply within several thousands of years (Shackleton 1977). Episodes of organic rich sedimentary deposition in the deep sea show high $\delta^{13} \mathrm{C}$ values for periods of several million years over all the oceans, e.g. in the Miocene (Berger \& Vincent 1986). Very sharp drops of $\delta^{13} \mathrm{C}$ are associated with mass extinction events e.g. at Permian-Triassic (Holser et al. 1986) and Frasnian-Famennian (Playford et al. 1984) boundaries. By analogy periods of intensive deposition of coal and coaly sediments might also be expected to show significant increase of marine dissolved carbonate $\delta^{13} \mathrm{C}$ values. Coaly sediments may be substantially preserved during transgressions, but mostly eroded during regressions. Therefore during an era of coaly deposition, a transgression, should be characterized by rising in $\delta^{13} \mathrm{C}$ values in marine carbonate rocks, followed by a regression with a sharp de- crease in ${ }^{13} \mathrm{C}$. We will present evidence of large variations in $\delta^{13} \mathrm{C}$ values in the Upper Palaeozoic sequence of North Greenland and relate them to large scale changes in sea-level.

\section{Regional setting}

The Late Palaeozoic sedimentation in the Wandel Sea Basin post-dates the Caledonian orogeny in Northeast Greenland and the Ellesmerian orogenesis in northern Greenland (Håkansson et al. 1981, Higgins et al. 1985, Hurst et al. 1985). Deposition of the Late Carboniferous to midPermian Mallemuk Mountain Group sediments was related to the structural development of two rift basins formed along the north and east coast of Greenland (figs 1, 2) (Stemmerik \& Håkansson in press).

The Mallemuk Mountain Group includes shelf carbonates, clastics and minor evaporites. Two major fining-upwards cycles of Late Carboniferous age are followed by widespread limestone deposition in the Early Permian. Major transgressions are recorded in the lower Moscovian, upper Moscovian, and middle Gzhelian part of the sequence (fig. 3). Deposition took place in 


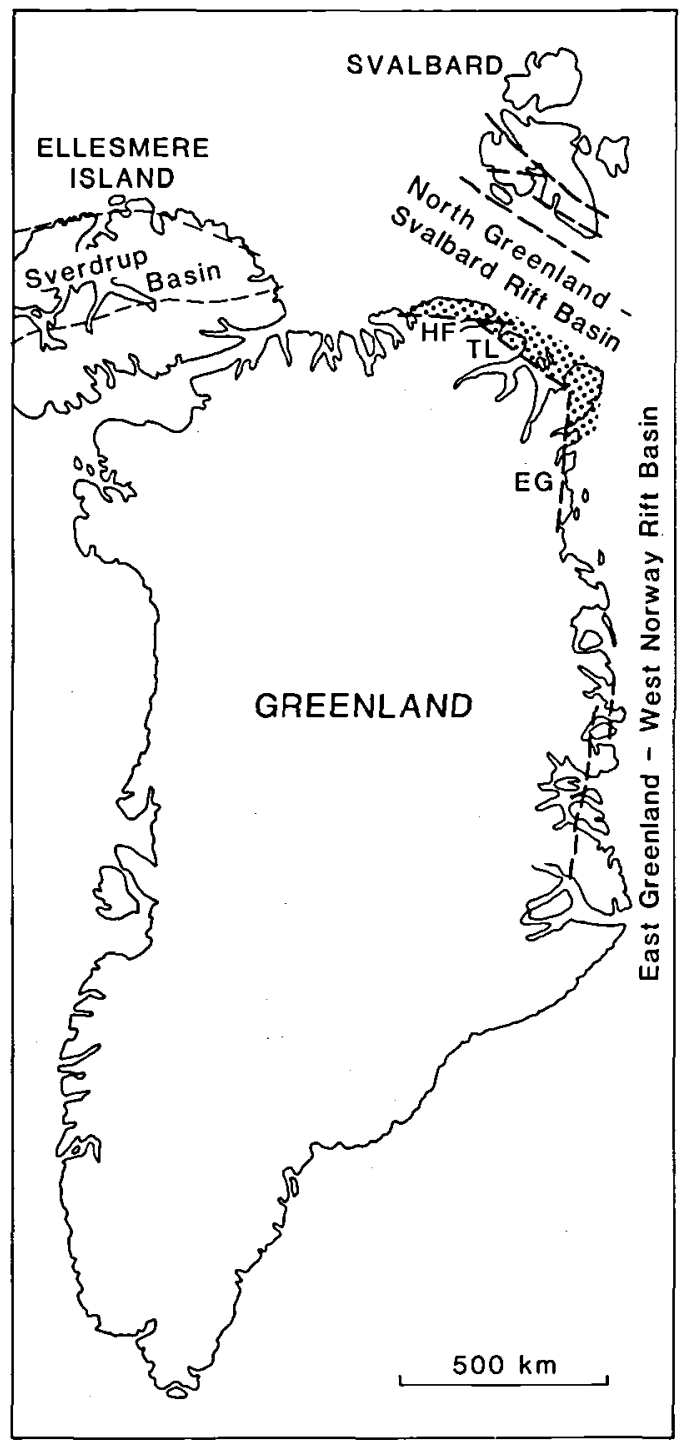

Fig. 1. General pre-drift configuration of Greenland, Ellesmere Island and Svalbard. The stippled area indicates the known extent of the Upper Palaeozoic basins. HF = Harder Fjord Fault Zone, $\mathrm{TL}=$ Trolle Land Fault Zone, EG = East Greenland Fault Zone.

partly isolated fault controlled basins making detailed lithological correlation between nearby areas difficult during the Late Carboniferous (Håkansson \& Stemmerik 1984, Stemmerik \& Håkansson in press). The gross pattern seen in the Wandel Sea Basin is, however, similar to that described from Svalbard (Steel \& Worsley 1984) and the Sverdrup Basin (Davies \& Nassichuk in press) implying that the depositional history to some degree was related to global changes in sea-level and the general northwards drift of the continents (Steel \& Worsley 1984). The similarity reached its climax in the Early Permian when carbonate platforms developed along the margins of the entire Arctic Basin.

Stable isotope measurements have been carried out during this study on samples from three sections (figs 2,3). The sections in Amdrup Land and Holm Land include sediments of Late Carboniferous to mid-Permian age (fig. 3). The Carboniferous to earliest Permian part of the sections is well dated on the basis of fusulinids and is easily correlatable to the Russian (and American) stages, although the precise boundary between the Wedekidellina and the Triticites zone is unknown (fig. 3) (Stemmerik \& Håkansson in press). The upper part of the Amdrup Land section yielded a rich brachiopod fauna (Dunbar 1962) which can be correlated to that found in the lower part of the Kapp Starostin Formation in Svalbard (Nakamura et al. 1987). This indicates a latest Early Permian or eventually an early Late Permian age for the upper part of the Mallemuk Mountain Group in this area.

The lower part of the section in Peary Land is dated by fusulinids (fig. 3) (Petryk 1977, Stemmerik \& Håkansson in press). The upper part of the Mallemuk Mountain Group is poorly dated in

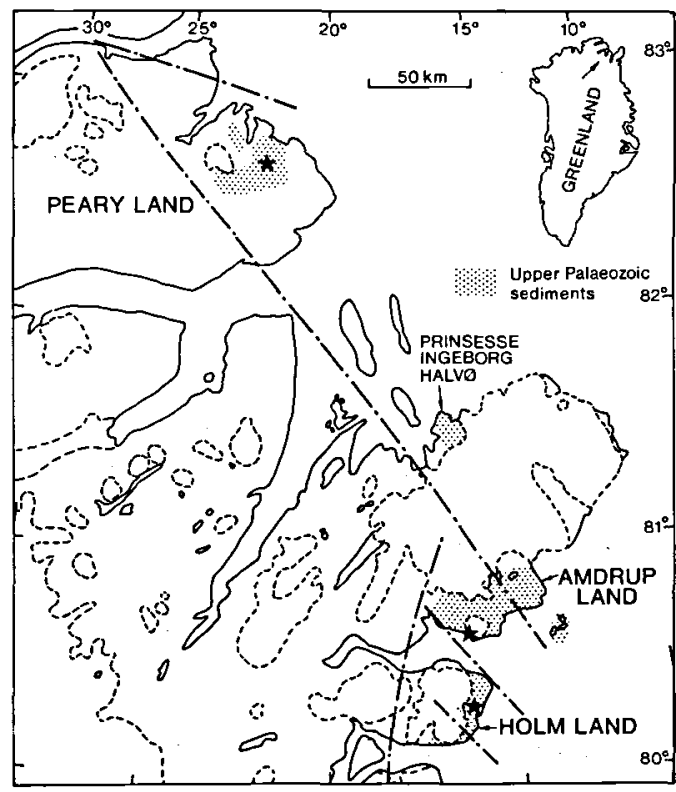

Fig. 2. Map of eastern North Greenland showing distribution of Upper Palaeozoic sediments and major structural elements. Location of analysed sections marked by asterix. 


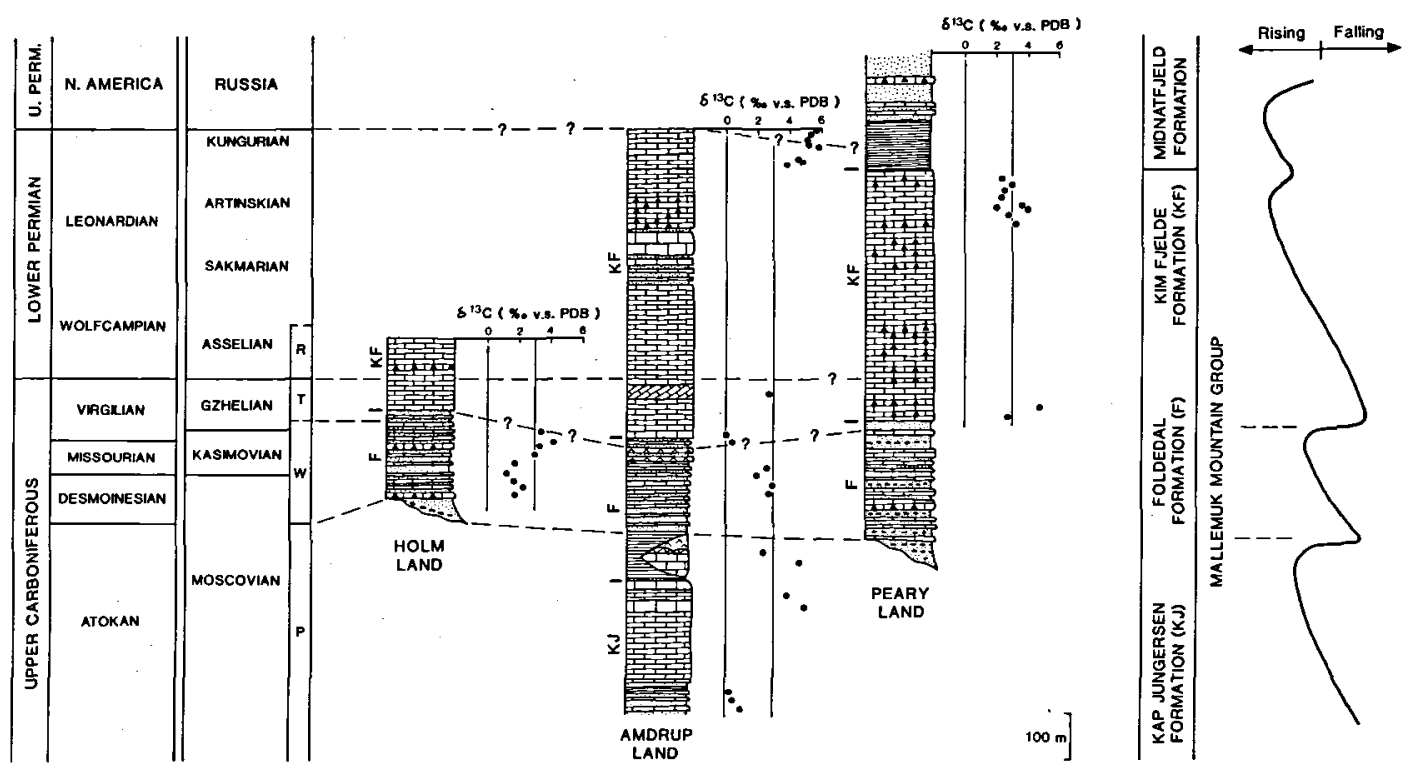

Fig. 3. Stratigraphic variation of $\delta^{13} \mathrm{C}$ in the northern Holm Land, southern Amdrup Land, and Peary Land sections. The dotted lines are proposed biostratigraphic correlation based on fusulinids. $\mathrm{P}=$ zone of Profusulinella, $\mathrm{W}=$ zone of Wedekidellina, $\mathrm{T}=\mathrm{zone}$ of Triticites, and $\mathbf{R}=$ zone of Rugosofusulina. $\mathrm{KJ}=\mathrm{Kap}$ Jungersen Formation, $\mathrm{F}=$ Foldedal Formation, and $\mathrm{KF}=\mathrm{Kim}$ Fjelde Formation. Lithology and strategraphy based on Håkansson \& Stemmerik (1984) and Stemmerik \& Håkansson (in press). The sea-level curve to the right shows a generalized trend of the regional changes in sea-level based on Stemmerik \& Worsley (in prep.).

this area. The overlying Midnatfjeld Formation yielded fossils of late Early Permian and Late Permian age (Håkansson 1979) suggesting an early Permian age for the youngest part of the Mallemuk Mountain Group in Peary Land. This means that the top part of the Mallemuk Mountain Group in Peary Land is slightly older than in Amdrup Land (fig. 3) (Håkansson \& Stemmerik 1984, Stemmerik \& Håkansson in press).

\section{Analytic Methods}

All analyses were performed on whole rock samples of shallow marine biogenic limestones and dolomites. An aliquot of the powder was analysed by standard X-ray diffraction procedure to detect the content of dolomite. Weighted percent dolomite/(dolomite + calcite) was calculated using the area under the peaks $\left(\mathrm{Cu}-\mathrm{K} 2 \Theta=30.8^{\circ}\right.$ and $29.5^{\circ}$ ) and the formula of Weber \& Smith (1961).

The carbon and oxygen isotopes in carbonate minerals were measured using the conventional phosphoric acid method (McCrea 1950). For samples containing more than $50 \%$ dolomite we used the procedure described by Magaritz \& Ka- fri (1981), measuring only the dolomitic component. The $\mathrm{CO}_{2}$ gas was analysed in a Varian M250 Mass spectrometer and results are given using the " $\delta$ " notation relative to the PDB standard (Table 1). The isotope values were calibrated using NBS 19 Calcite standard $\left(\delta^{18} \mathrm{O}=-2.20 \%\right.$, $\delta^{13} \mathrm{C}=$ $1.96 \%$ ).

Reproducibility of duplicate samples is better than $0.1 \%$ for $\delta^{13} \mathrm{C}$ and $0.15 \%$ for $\delta^{18} \mathrm{O}$.

The problems using whole rock analyses in isotopic work have been discussed by Beauchamp et al. (1987). The rocks analysed in the present study are dominantly unaltered shallow-water limestones in the sense of Beauchamp et al. (1987). However, aragonitic components in wackestones and packstones have been replaced by sparry calcite. The dolomite is microcrystalline to finely crystalline preserving the original texture of the sediment. In limestone and dolomite, changes in the carbon isotopic value vary with time by a different amount from the changes in oxygen isotopic value. This behaviour can be understood by considering the material balance of the whole diagenetic system (i.e. sediment plus pore water). It has been shown (Magaritz 1983) that there are only few carbon ions in solution in such a system. So, in order for there to be a small 
Table 1. Carbon and oxygen isotopic ratios, and dolomite percentages of the analysed carbonate samples.

\begin{tabular}{|c|c|c|c|}
\hline GGU No. & $\delta^{13} \mathrm{C}$ & $\delta^{18} \mathrm{O}$ & $\%$ dol \\
\hline 196130 & 4.40 & -8.9 & 0 \\
\hline 196138 & 2.75 & -6.9 & 0 \\
\hline 196201 & 3.65 & -7.8 & 0 \\
\hline 196204 & 2.88 & -8.3 & 0 \\
\hline 196218 & 3.97 & -5.5 & 0 \\
\hline 196220 & 2.26 & -9.3 & 0 \\
\hline 196222 & 2.55 & -7.7 & 56 \\
\hline 196224 & 3.01 & -6.8 & 0 \\
\hline 196228 & 2.31 & -6.9 & 0 \\
\hline 220655 & 0.30 & -8.6 & 0 \\
\hline 220656 & 0.36 & -8.1 & 0 \\
\hline 220658 & 0.90 & -8.2 & 0 \\
\hline 221346 & 2.84 & -0.2 & 100 \\
\hline 221348 & 3.05 & -0.9 & 100 \\
\hline 221349 & 2.05 & -1.3 & 95 \\
\hline 221351 & 2.63 & +0.7 & 95 \\
\hline 221363 & 3.86 & -2.9 & 0 \\
\hline 221364 & 4.87 & -5.5 & 0 \\
\hline 221365 & 4.61 & -6.8 & 0 \\
\hline 221366 & 5.94 & -5.2 & 0 \\
\hline 221367 & 5.25 & -5.6 & 0 \\
\hline 221368 & 5.24 & -5.1 & 0 \\
\hline 221370 & 5.35 & -5.4 & 0 \\
\hline 221371 & 5.66 & -7.6 & 0 \\
\hline 221374 & 4.90 & -1.8 & 100 \\
\hline 221375 & 3.86 & -1.9 & 100 \\
\hline 221377 & 4.68 & -1.7 & 93 \\
\hline 221378 & 2.29 & -5.3 & 88 \\
\hline 221382 & 2.18 & -2.2 & 56 \\
\hline 221384 & 0.02 & -8.0 & 27 \\
\hline 221386 & 2.79 & -5.6 & 0 \\
\hline 221392 & 1.91 & -9.2 & 0 \\
\hline 221393 & 2.41 & -5.9 & 60 \\
\hline 221394 & 1.87 & -7.3 & 0 \\
\hline 221395 & 1.27 & -9.1 & 0 \\
\hline 221396 & 1.97 & -6.8 & 0 \\
\hline 221397 & 3.19 & -7.8 & 0 \\
\hline 221398 & 3.43 & -7.0 & 0 \\
\hline 221399 & -0.45 & -7.5 & 0 \\
\hline 221400 & 3.50 & -6.8 & 51 \\
\hline
\end{tabular}

shift in $\delta^{13} \mathrm{C}$ in the solid phase, at least 1500 times the pore volume of solution must pass through the system. The same change in $\delta^{18} \mathrm{O}$ can happen if only 5 times the pore volume of solution passes through. Since these values are minima (they assume that exchange occurs with every atom in the fluid), the actual amounts of fluid needed to affect a change in the $\delta^{13} \mathrm{C}$ values are likely to be even larger.

This model is supported by evidence from carbonate cements, which are formed entirely during diagenesis. Allan \& Matthews $(1977,1982)$ explained the marine range of $\delta^{13} \mathrm{C}$ values in the meteoric waters in these cements as the result of repeated cycles of dissolution and precipitation. Thus the value of $\delta^{13} \mathrm{C}$ in the pore water gradually approached that in the marine carbonate. Dickson \& Coleman (1980) found a similar marine range of $\delta^{13} \mathrm{C}$ and proposed that the main source of carbon in pore solution is dissolution of marine carbonates. Thus it is believed that diagenesis has had negligible effect on the $\mathrm{C}$-isotope composition, and the measured values represent primary differences.

\section{Results}

Carbon isotope values vary from almost $0 \%$ to $+5.7 \%$ in the Upper Carboniferous to Lower Permian limestones of the Wandel Sea Basin (fig. 3). Though not sampled in detail one can detect a trend of the $\delta^{13} \mathrm{C}$ values which apparently correlates to the depositional pattern (fig. 3). $\delta^{13} \mathrm{C}$ values are low $(+0.3$ to $+0.9 \%$ ) in the basal part of the lower Moscovian Kap Jungersen Formation becoming much enriched in ${ }^{13} \mathrm{C}$ (2.3 to 4.9 $\%$ ) in the upper part. The upper Moscovian mid Gzhelian Foldedal Formation was analysed in two sections $30 \mathrm{~km}$ apart. The carbonates have low $\delta^{13} \mathrm{C}$ values at the base $(1.3-2.4 \%$ ) and higher values 2.0 to $3.5 \%$ near the top (fig. 3 ). The topmost limestone bed in the Foldedal Formation marking the beginning of a regional transgression has a $\delta^{13} \mathrm{C}$ value of $0.4 \%$ dropping to 0.0 $\%$ at the base of the Gzhelian-Permian Kim Fjelde Formation (fig. 3). The $\delta^{13} \mathrm{C}$ values increase to $2.8-4.4 \%$ higher in the sequence (fig. 3). Further enrichment from $3.8 \%$ to values above $5 \%$ is recorded in the topmost part of the formation in Amdrup Land.

$\delta^{18} \mathrm{O}$ values show ${ }^{18} \mathrm{O}$ depletion in most calcitic samples with values in the range -3.0 to $-9.3 \%$. These values, unlike the $\delta^{13} \mathrm{C}$ values, indicate post-depositional alteration of marine values, commonly found in ancient limestones (Magaritz 1975). $\delta^{18} \mathrm{O}$ values of dolomite samples are more enriched in ${ }^{18} \mathrm{O}$ ( +0.7 to $-1.9 \%$ ) (fig. 4$)$.

\section{Discussion}

Although the sampling is not of great detail, a general picture of $\delta^{13} \mathrm{C}$ variation in the early Moscovian to Kungurian or earliest Late Permian can be obtained. At least three carbon isotope cycles (from ${ }^{13} \mathrm{C}$ depleted to ${ }^{13} \mathrm{C}$ enriched carbonate) 


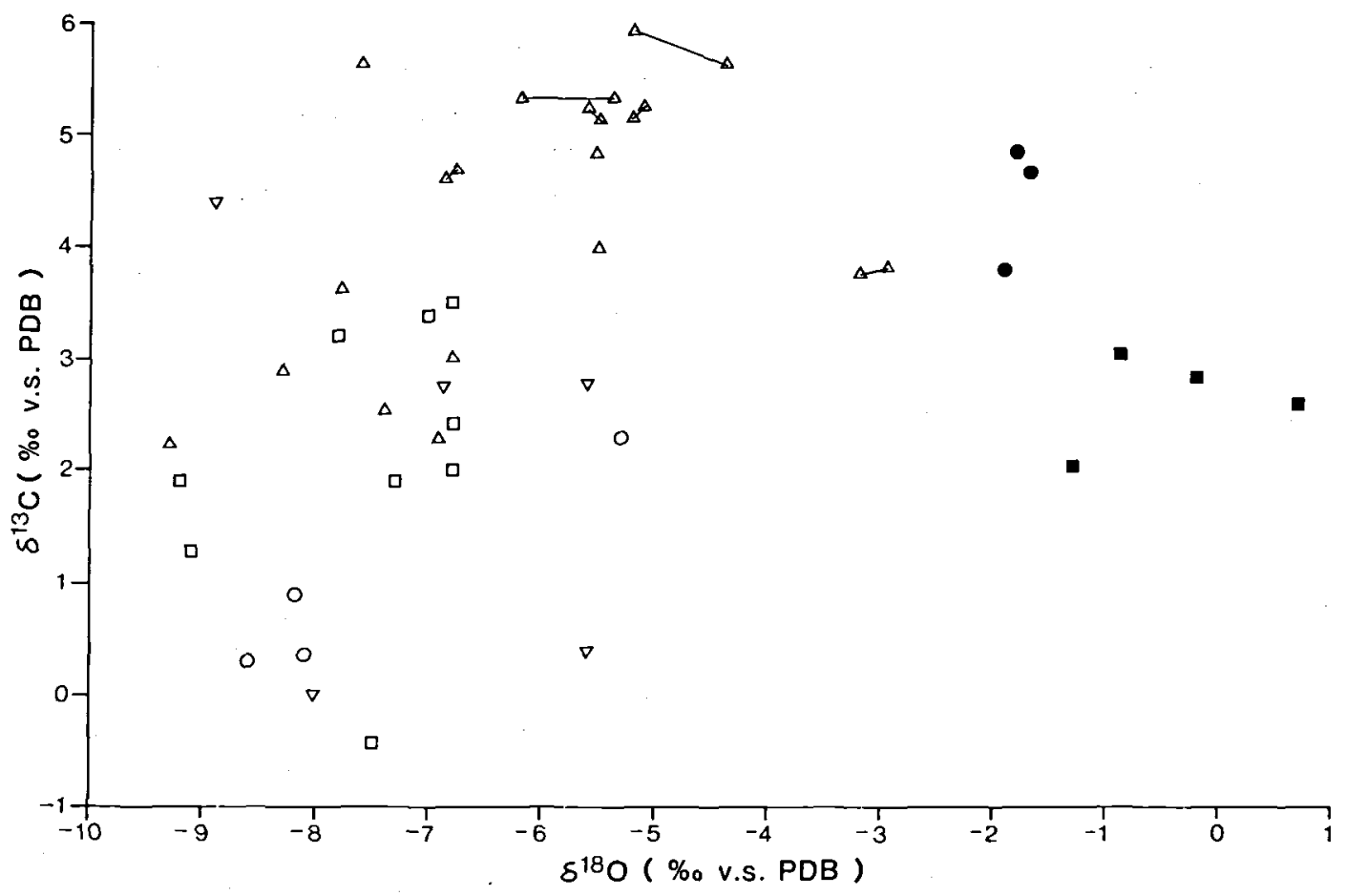

CALCITE DOLOMITE

$\begin{array}{lll}\Delta & \text { Lower Permian - ? lower Upper Permian } \\ \nabla & \text { upper Gzhelian } \\ \square & \text { - } & \text { upper Moscovian - lower Gzhelian } \\ \circ & \text { - lower Moscovian }\end{array}$

Fig. 4. Carbon and oxygen isotope composition of the investigated Late Palaeozoic limestones and dolomites.

were detected. A similar pattern was detected in a section through Upper Carboniferous of the Pedregosa Basin, New Mexico (Holser \& Magaritz unpubl. data). There, $\delta^{13} \mathrm{C}$ values varied from more negative values at the base of the Atokan, Desmoinesian and Missourian transgressive sequences to more ${ }^{13} \mathrm{C}$ enriched values higher in each of the sequences. The similarity of the general carbon isotope pattern between the North Greenland and SW USA sections may support a model which relates the fluctuation of $\delta^{13} \mathrm{C}$ values to changes in sea-level caused by the frequent glaciations occurring during the Upper Palaeozoic. At the beginning of a transgression $\delta^{13} \mathrm{C}$ values are low, becoming enriched in ${ }^{13} \mathrm{C}$ towards the peak of the transgression. The reason for this sea-level dependent change in the oceanic $\delta^{13} \mathrm{C}$ is suggested to be erosion and oxidation of the organic carbon stored on the shelfs and near coastal regions during sea-level low stands and increased accumulation of organic carbon during sea-level high stand. The model of $\delta^{13} \mathrm{C}$ increase in marine carbonate with transgressive phases of deglaciation was discussed in relation to the Upper Pleistocene (Shackleton 1977, Broecker \& Takahashi 1984). The place where the organic carbon was stored during the late Pleistocene is not yet known, but may be in the rain forest or on the extended shelf, whereas in the late Palaeozoic it probably was stored as coal. Two different types of $\mathrm{C}_{\mathrm{org}}$ storage exist: a) Biomass accumulation (e.g. tropical forest) as part of the ecological system which has capacity to store only a limited amount of biomass but is capable to change the 
stored volume over very short periods of time, and b) Burial storage of biomass (e.g. coal) where the biomass potential stored is much greater and the time involved much longer. One can suggest that the Upper Pleistocene carbon isotope shift relates to type ' $a$ ' storage while the much more significant shifts in the Upper Palaeozoic relate to type ' $b$ ' storage. This may explain the enrichment recorded in the uppermost part of the Amdrup Land section where $\delta^{13} \mathrm{C}$ values range between $4 \%$ and $6 \%$ (fig. 3 ). These values are comparable to values recorded in the Upper Permian of East Greenland (Clemmensen et al. 1985, Magaritz \& Stemmerik unpublished data) and in other Upper Permian sequences of Northern and Southern Europe and Southeast USA (Holser et al. 1986) supporting a suggested late Early Permian to early Late Permian age of this part of the sequence.

Beauchamp et al. (1987) recorded rather uniform and high $\delta^{13} \mathrm{C}$ values from Late Palaeozoic limestones in the Sverdrup Basin in Arctic Canada contrasting the cyclic pattern found in North Greenland. The $\delta^{13} \mathrm{C}$ values recorded from the Sverdrup Basin (Beauchamp et al. 1987) are similar to the ${ }^{13} \mathrm{C}$ enriched values found in the Upper Carboniferous and topmost Permian parts of the sections in Greenland. Lower Permian values in contrast are enriched ca. $2 \%$ in the Sverdrup Basin.

Beauchamp et al. (1987) proposed a model for the Sverdrup Basin values involving ${ }^{13} \mathrm{C}$ enrichment due to local storage of organic carbon and deposition of evaporites in an enclosed basin. Limited water exchange with the ocean and limited exchange with the atmosphere due to proposed low atmospheric pressure was suggested as a mechanism keeping the Sverdrup Basin in isotopic unbalance to the ocean (Beauchamp et al. 1987). The high $\delta^{13} \mathrm{C}$ values recorded in the Upper Carboniferous sequences of the Sverdrup and Wandel Sea Basins compared to elsewhere (e.g. Veizer et al. 1980, Brand 1981) imply interconnection of the two basins as previously suggested on basis of stratigraphic similarities (e.g. Steel \& Worsley 1984, Davies \& Nassichuk in press, Stemmerik \& Håkansson in press). The absence of a cyclic pattern of $\delta^{13} \mathrm{C}$ in the Sverdrup Basin comparable to that described from the Wandel Sea Basin may be explained in two ways: 1) The narrow intervals yielding depleted ${ }^{13} \mathrm{C}$ in North
Greenland have not been analysed in the study of Beauchamp et al. (1987), or 2) The semi-enclosure of the Sverdrup Basin prevented the transgressive sea from reaching the basin until a very late stage of the transgression. The dissolved inorganic carbon in the sea-water then will be considerably less depleted in ${ }^{13} \mathrm{C}$ and mixing with ${ }^{13} \mathrm{C}$ enriched water from the deeper parts of the basin probably will make the differences in $\delta^{13} \mathrm{C}$ values between limestones of different cycles too small to be recorded.

\section{Conclusions}

Carbon isotope studies of Late Palaeozoic limestones in the Wandel Sea Basin show a cyclic pattern of ${ }^{13} \mathrm{C}$ with time. Low values of $\delta^{13} \mathrm{C}(0.0$ $\% o-1.0 \%$ ) are confined to the basal transgressive stages of three major fining-upwards cycles each corresponding to a formation within the Mallemuk Mountain Group. Later in each of the transgressive cycles carbonates are enriched in ${ }^{13} \mathrm{C}$ having $\delta^{13} \mathrm{C}$ values in the range $2-4.5 \%$.

The high values found in the Sverdrup Basin and the Wandel Sea Basin suggest that the two basins were connected during the Late Palaeozoic and somehow had only limited water exchange to the ocean.

Acknowledgements. We would like to thank W.T. Holser for helpful comments. R. Selnikov and N. Awad did the mass spectrometry and X-ray measurements, $M$. Larsen the typing and $B$. Sikker Hansen the drawings. The results are published with the permission of the Director of the Geological Survey of Greenland. This article is a contribution to IGCP Project 216: Global Bio-events. This work was supported by the Danish Natural Science Research Council through grant 11-7010.

\section{Dansk sammendrag}

Isotopunders $\emptyset$ gelser af Sen Palæozoiske kalksten fra Wandel Sea Basin i det østlige Nordgrønland viser en variation i $\delta^{13} \mathrm{C}$ fra $0.0 \%$ til $5.7 \%$ relativt til PDB. Kalksten fattige på ${ }^{13} \mathrm{C}$ forekommer $i$ den nederste del af transgressive sekvenser, mens kalksten rige på ${ }^{13} \mathrm{C}$ forekommer under maksimal transgression.

Det er postuleret, at isotopskiftene skyldes skift i det globale kulstofkredsløb, således at kalksten rige på ${ }^{13} \mathrm{C}$ dannes i perioder, hvor der er stor ophobning af organisk kulstof i form af kul. Kalksten fattige på ${ }^{13} \mathrm{C}$ dannes i perioder, hvor havniveau 
er lavt og det ophobede kulstof derfor bliver eroderet og oxideret.

\section{References}

Allan, J. R. \& Matthews, 1977: Carbon and oxygen isotopes as diagenetic and stratigraphic tools: surface and subsurface data Barbados, West Indies. Geology, 5, 16-20.

Allan, J. R. \& Matthews, 1982: Isotope signatures associates with early meteoric diagenesis. Sedimentol., 29, 797-817.

Beauchamp, B. Oldershaw, A.E. \& Krouse, H.R. 1987: Upper Carboniferous to Upper Permian ${ }^{13} \mathrm{C}$-enriched primary carbonates in the Sverdrup Basin, Canadian Arctic: comparisons to coeval western American ocean margins. Chem. Geol., (Isotope Geoscience Section), 65, 391-413.

Berger, W. H. \& Vincent, E. 1986: Deep-sea carbonates. Reading the carbon isotope signal. Geol. Rundschau, 75, 249-269.

Brand, U. 1981: Mineralogy and chemistry of the Lower Pennsylvanian Kendrick fauna, eastern Kentucky, 2. Stable isotopes. Chem. Geol., 32, 17-28.

Broecker, W. S. \& Takahashi, T. 1984: Is there a tie between atmospheric $\mathrm{CO}_{2}$ content and ocean circulation? Amer. Geophys. Un. Geophys. Monogr. 28, 314-326.

Clemmensen, L., Holser, W. T. \& Winter, D. 1985: Stable isotope study through the Permian-Triassic boundary in East Greenland. Bull. geol. Soc. Denmark, 33, 253-260.

Davies, G. R. \& Nassichuk, W. W. in press: Carboniferous and Permian history of the Sverdrup Basin, Arctic Islands. In Trettin, H. P. (edit.) The Innuitian Region. The Geology of North America E. Geol. Suv. Canada, Ottawa.

Dickson, J. A. D. \& Coleman, M. L. 1980: Changes in carbon and oxygen isotope composition during limestone diagenesis. Sedimentol. 17, 107-118.

Dunbar, C.O. 1962: Faunas and correlation of the Late Palaeozoic rocks of Northeast Greenland. Part 3. Brachiopoda. Meddr Grønland 167 (6), 14 pp.

Higgins, A. K., Soper, N. J. \& Friderichsen, J. D. 1985: North Greenland fold belt in eastern North Greenland. In Gee, D. G. \& Sturt, B. A. (eds.) The Caledonide Orogen Scandinavia and related areas, 1017-1029.

Holser W. T. 1984: Gradual and abrupt shifts in ocean chemistry during Phanerozoic time. In H. D. Holland \& A. G. Trendall (eds): Patterns of change in earth evolution. Springer-Verlag, Berlin, 123-143.

Holser, W. T., Magaritz, M. \& Clark, D. L. 1986: Carbonisotope stratigraphic correlations in the Late Permian. Amer. J. Sci., 286, 390-402.

Hurst, J. M., Jepsen, H. F., Kalsbeek, F., McKerrow, W. S. \& Peel, J. S. 1985: The geology of the northern extremity of the East Greenland Caledonides. In Gee, D. G. \& Sturt, B. A. (edit.) The Caledonide Orogen-Scandinavia and related areas, 1047-1063.
Hảkansson, E. 1979: Carboniferous to Tertiary development of the Wandel Sea Basin, eastern North Greenland. Rapp. Gronlands geol. Unders., 88, 73-83.

Håkansson, E. Heinberg, C. \& Stemmerik, L. 1981: The Wandel Sea Basin from Holm Land to Lockwood $\emptyset$, eastern North Greenland. Rapp. Gronlands geol. Unders., 106, $47-63$.

Håkansson, E. \& Stemmerik, L. 1984: Wandel Sea Basin-the North Greenland equivalent to Svalbard and the Barents Shelf. In Spencer, A. M. et al. (eds.) Petroleum Geology of the North European Margin. Graham \& Trotman for the Norwegian Petroleum Society, 97-107.

Magaritz, M. 1975: Sparitization of a pelleted limestone: a case study of carbon and oxygen isotopic composition. Jour. Sediment. Petrol. 45, 599-603.

Magaritz, M. 1983: Carbon and oxygen isotope composition of recent and ancient coated grains. In Peryt, T. M. (ed.): Coated Grains, Springer Verlag, Berlin, 27-37.

Magaritz, M. \& Kafri, U. 1981: Stable isotope and $\mathrm{Sr}^{2+} / \mathrm{Ca}^{2+}$ evidence of diagenetic dedolomitization in a schizohaline environment: Cenomanian of northern Israel. Sediment. Geol., 28, 29-41.

McCrea, M. 1950: On the isotopic chemistry of carbonates and a paleotemperature scale. J. Chem. Phys. 18, 849-857.

Nakamura, K., Kimura, G. \& Winsnes, T. S. 1987: Brachiopod zonation and age of the Permian Kapp Starostin Formation (Central Spitsbergen). Polar Research 5, 207-219.

Petryk, A. A. 1977: Upper Carboniferous (Late Pennsylvanian) microfossils from the Wandel Sea Basin, Peary Land, eastern North Greenland. Rapp. Gronlands geol. Unders., $85,16-21$.

Playford, P. E., McLasen, D. J., Orth, C. J., Gilmore, J. S. \& Goodfellow, W. D. 1984: Iridium anomaly in the Upper Devonian of the Canning Basin, Western Australia. Science, 226, 437-439.

Shackleton, N. J. 1977: Carbon-13 in Urigerina: Tropical rainforest history and the equatorial Pacific carbonate dissolution cycles. In Andersen, N. R. \& Malahoff, A. (eds.): The fate of fossil fuel $\mathrm{CO}_{2}$ in the oceans. Plenum Press, New York, 401-427.

Steel, R. J \& Worsley, D. 1984: Svalbards post-Caledonian strata - an atlas of sedimentational patterns and palaeogeographic evolution. In Spencer, A. M. et al. (eds.) Petroleum Geology of the North European Margin. Graham \& Trotman for the Norwegian Petroleum Society, 109-135.

Stemmerik, L. \& Håkansson, E. in press: Stratigraphy and depositional history of the Upper Palaeozoic and Triassic sediments in the Wandel Sea Basin, eastern North Greenland. Rapp. Gronlands geol. Unders.

Veizer, J., Holser, W. T. \& Wilgus, C. K. 1980: Correlation of ${ }^{13} \mathrm{C} /{ }^{12} \mathrm{C}$ and ${ }^{34} \mathrm{~S} /{ }^{32} \mathrm{~S}$ secular variations. Geochim. Cosmochim. Acta, 44, 579-587.

Weber, J. N. \& Smith, F. G. 1961: Rapid determination of calcite ratios in sedimentary rocks. J. Sediment. Petrol., 31, 130-131. 